Tourism Research Journal

E-ISSN: 2598-9839

2019, Vol. 3 No. 2

\title{
Analysis of The Effect of Price Determination on Hotel Revenue (Hotel Case in Puncak, Bogor)
}

\author{
Anita Swantari ${ }^{1}$, Devita Gantina ${ }^{2}$, Filma Festivalia ${ }^{3}$ \\ 1,2,3 Sekolah Tinggi Pariwisata Trisakti \\ 1anitaswantari@stptrisakti.ac.id \\ 2devita@stptrisakti.ac.id \\ 3filmaf.Andjar@stptrisakti.ac.id
}

\begin{abstract}
The purpose of this study is to find out the percentage of room occupancy and the room rates correlated with the benefits gained by the hotel in Puncak Bogor in the period of 2016 - 2018. This research includes the type of Descriptive and Explanatory Research of variables of prices, occupancies and incomes received by the hotel. It can be seen that the influence of price determination as measured by the room occupancy rates to the amount of hotel revenue is shown by the regression coefficient test, so, it can be stated that the occupancy rate or the number of visitors staying overnight has a very significant influence on the increase of hotel revenues.
\end{abstract}

Keywords: Pricing, Room Occupancy Rate, Hotel Revenue 


\section{A. Introduction}

Hotel as one type of business in service from the perspective of prospects and challenges has a dichotomic nature, where in terms of prospects it is considered quite good but from the other side is vulnerable to all risks that will be faced. This business is classified as capital intensive so it requires a long time to return the capital, so the factors that influence the success and the risk are very diverse. This causes the hotel to be managed professionally, so that it can continue in the face of very high competition. As with other businesses, the hotel management must still refer to efforts to maximize profits.

Decisions about pricing are influenced by many factors, according to Fandi Tjiptono (2000: 154) internal factors and external factors. This parameter in the hotel business is often associated with the percentage of hotel room occupancy. This measure is directly related to the amount of revenue, expenses and the desired level of profit. How big is the occupancy rate of the room which is considered quite profitable is certainly different from one hotel to another hotel. Therefore, to manage the hotel properly, it is important to know how far the percentage of the occupancy rate of the room correlates with the profits obtained by a particular hotel during a certain period.

\section{B. Literature Review}

\section{Hotel Management}

Hotel management is a hotel management activity that is based on management concepts. According to Sutopo and Suryanto (2003: 9), hotel management is a business that is engaged in services, with the scope of its movement to sell rental services for bedrooms, complete with all hotel operational facilities. In the end it was concluded that in managing the hotel, maximum service should be made to make guests feel at home and with a distinct impression is expected to make it back again. In other words, that the management of a hotel is all the efforts made to make the hotel sell well and be liked by its guests in order to create the hotel into an area of business that brings maximum money or profits.

\section{Total Hotel Revenue}

Goodman (2000; 25-35) states that the Total Revenue is the result of the collection and total acquisition of all revenue generated from the sale of its products at an agreed price. Revenue is a major and important element of financial statements. According to N Lapoliwa, Daniel S Kuswandi (2000) "Revenue is the result of assets distributed to the public or in the form of investment (investment)". Revenue is the gross inflow of economic benefits arising from the normal activities of an entity during a period, if the inflows result in an increase in equity that does not originate from investment contributions. Financial Accounting Standards NO.23 defines revenue as follows: Revenue is the gross inflow of economic benefits arising from the 
normal activities of a company during a period if the inflows result in an increase in equity that does not originate from investment contributions.

\section{Pricing}

The price of a product is a measure of the size of the value of one's satisfaction with the product bought. Someone will dare to pay a product with a high price if he assesses the expected satisfaction with the product he bought is high. Conversely, if someone assesses his satisfaction with a product is low, then he will not be willing to pay a high price. Economic value is created by activities that occur in the market mechanism between sellers and buyers. In a purchase transaction, then both parties will get a reward, the size of the reward is determined by the difference between the value of something received. The excess value received by that given by a company is called profit.

According to Basu Swastha (2010: 147), price is the amount of money (plus some products if possible) needed to get a combination of goods and services. According to Swastha and Soekotjo (1993; 23) the pricing procedure consists of:

- Estimating demand for the item. In this stage the seller makes an estimate of the total demand for his goods, estimating the request can be done by:

- Determine the expected price (expected price) Namely the price expected to be accepted by consumers.

- Estimating sales volumes at various price levels This also involves consideration of the elasticity of demand for an item. Goods that have elastic market demand, will usually be priced more than goods that have in elastic demand.

- Knowing in advance the reaction in competition Competition conditions greatly affect the pricing policy for the company or seller, therefore the seller needs to know the competition reaction that occurs in the market and the sources of the cause.

\section{Room Occupancy Rate}

According to Darmadjati, in Imelda. P and Aris F. W. (2002: 23) referred to as room occupancy is a condition of hotel room occupancy, which is the ratio between the number of rooms sold to the number of rooms available in a particular product. Tourism is a key element for hotels' occupancy as hotels are closely linked with the tourism industry (Sharma and Srivastava, 2018).

Room Occupancy $=\underline{\text { Room Sold }}$

Room Available

The room occupancy rate is generally calculated in percentages by multiplying the equation above by $100 \%$. Room occupancy rates indicate the number of room presentations inhabited by guests. There are also room occupancy rates calculated by room units to find out the number of rooms sold 
in a certain period, for example one semester or one year. Roughly speaking, the percentage of occupancy rate of a room indicates the hotel's ability to attract

\section{Penetration Pricing}

In this case, in order to succeed, several conditions must be met, namely: the market is so sensitive that low prices can stimulate growth or demand for potential buyers with as much production experience as possible to reduce production and distribution costs. Considering the politics of corporate marketing by looking at goods, distribution systems and promotional programs.

Decisions about pricing are influenced by many factors, according to Fandi Tjiptono (2000: 154) internal factors and external factors include:

\section{Internal Factors of the Company}

The company's marketing goals: the main determining factor in pricing is the company's marketing objectives. These objectives can be in the form of profit maximization, maintaining the viability of the company, gaining a large market share and others. Marketing mix strategy: price is only one component in the marketing mix. Therefore prices need to be coordinated and mutually supportive with other marketing mixes, namely: products, distribution and promotion. Cost: Cost is the factor that determines the minimum price that must be set so that the company does not suffer losses.

\section{External Factors of the Company}

a. The nature of markets and demand

Every company needs to understand the nature of the market and the demand it faces, whether it includes perfect competition, monopilistic competition, oligopoly or monopoly.

\section{b. Competition}

There are five main forces that influence competition in an industry including: products, substitutions, suppliers, customers and the threat of new entrants. Therefore companies need information to analyze the characteristics of the competition faced.

\section{This information can be obtained through:}

- Number of companies in the industry: if there is only one company in the industry, theoretically the company concerned is free to set any price. But on the contrary, if the industry consists of many companies, price competition will occur. If the resulting product is undifferentiated, only industry leaders are free to determine price changes.

- Relative size: if the company has a large market share, then the company concerned can hold the price change initiative. If the market share is small, then only become followers.

- Product differentiation: if the company has a chance of differentiation in its industry, then the company can control aspects of pricing, even if the company is small and has many competitors in the industry. 
- $\quad$ Ease of entering the relevant industry: if an industry is easily entered, then the existing company is difficult to influence the price. Meanwhile, if there are obstacles to enter the market, companies already in the industry can control prices.

Barriers to entering the market can be:

a. Industry requirements

b. Large capital investment

c. Unavailability of raw materials

d. Constraints on natural resources

e. Expertise in marketing

- Other external elements: in addition to the above factors, the company also needs to consider factors of economic conditions (inflation, interest rates), government policies and regulations and social aspects (environmental stewardship). With the factors that can affect consumers and producers, the company must be able to determine the appropriate pricing so that the goods and services produced can be accepted by consumers.

According to Kotler and Armstrong (2010) suggested the pricing strategy, as follows:

1. Mark up Pricing

The selling price is determined based on the presentation of expected profits added to the overall production costs as costs or profits

2. Target Return Pricing

The company determines the price level that will produce a return with a predetermined target.

3. Percevied Value Pricing

Prices are determined based on consumer ratings of the product, if

The consumer values the product high then the price set or the product too high.

4. Going Rate Pricing

Existing prices follow the existing market prices based on selling prices set by competitors.

5. Sealed Bid Pricing

The price is determined based on the company's assumptions about how much the price will be set by competitors, not the cost and the request itself is used when the company wants to win the product.

\section{Research methods}

This type of research is a type of Descriptive Research, because it aims to describe and explain the variables about prices, occupancy rates and income received by hotels in Puncak Bogor. Determination of the object of research by considering the ease in obtaining data and besides the existence of the required data. The unit of analysis in this study is price, occupancy and income from 2016 - 2018. 
Data sources used in this study are secondary data sources, in the form of average room prices, occupancy rates, and hotel income. The data is obtained through annual reports in 2016, 2017, and 2018. From this data can be informed, the average price every month from January to December for 3 years, ie from 2016 to 2018. Likewise, the average level occupancy and average hotel income. Primary data source (only used as a supplement and not processed in detail). The data collection method in this study used observation and interviews with the General Manger, Front Office Manager and Chief Accounting to identify the hotel.

\section{Discussion}

\section{Descriptive Analysis \\ a. Pricing}

Any company hopes that the right pricing can get good results and is useful for the company. In setting prices for each product sold, the company emphasizes the costs. This shows that any increase in costs will result in price increases which will affect the hotel revenue. In setting room prices per day, the hotel strives to provide confidence to visitors about the service that can be enjoyed, namely at prices that are tailored to the ability according to its class, providing services that can satisfy visitors.

In setting prices, Hotels use pricing based on the best service, which has been determined. In this case there are several factors that cause the hotel to review existing price fixing, including: a) There are changes in the marketing environment, for example, there are large competitors who reduce prices, b) There is a shift in demand, for example changes in customer tastes, c) There is an economic crisis, for example soaring prices to meet the services provided.

In setting prices, Hotels use pricing based on the best service, which has been determined. In this case there are several factors that cause the hotel to review existing price fixing, including: a) There are changes in the marketing environment, for example, there are large competitors who reduce prices, b) There is a shift in demand, for example changes in customer tastes, c) There is an economic crisis, for example soaring prices to meet the services provided.

Revaluation of the price that was previously carried out, there are three alternatives carried out, namely: a) Maintaining prices, b) Lowering prices, c) Increasing prices. Hotels, always pay attention to price conditions prevailing in the market or other competitors. So that the pricing used can be successful and able to increase the expected income, and always maintain and improve the quality of services provided to guests. This is done because at this time guests are always careful in carrying out their consumption activities, especially in prices, with the intention of not losing the costs already incurred.

In an effort to sell their products, there are some hotels that sell only room products, but with breakfast (room with breakfast) or there is also in a package (packaging) in an integrated "package", such as: weekend package, 
seasonal package ( Christmas, Eid, New Year), wedding packages or what is currently a trend is the "Meeting package" because it is proven to be quite resistant to the turmoil of changes that occur in the market, especially the market share of foreign tourists. In sales with a packaging system, several prices have been calculated in the form of packages and are sold and then redistributed at each outlet, for example:

Weekend Rate; sold at Rp. 300,000.00, -net, this special price includes breakfast for two people and $21 \%$ tax and service. In addition, additional facilities such as late check-out up to 16.00 are provided at no additional cost, and free use of the swimming pool and free entrance to the Gym room (free entrance). Whereas on a normal day, the price of a normal room is IDR 450,000 excluding breakfast and $21 \%$ service tax or guests must pay the following:

\begin{tabular}{ll} 
Room Rate & Rp. 450.000 \\
Service Charge10\% & Rp. 45.000 \\
\cline { 2 - 2 } Sub Total & Rp. 495.000 \\
Pajak 11\% & Rp. 49.500 \\
\cline { 2 - 2 } Total to be paid & Rp. $544.500,-$
\end{tabular}

Meeting Package; starting at Rp. 110,000 net / person per day (one room two people / twin sharing). The rate (price) for the meeting package, including room accommodation for two people, taxes and services, two coffee breaks, meeting rooms with room capacities ranging from 20 people to 200 people, and a buffet lunch (Buffet Luncheon) in the restaurant.

Following are the results of research on price changes (tariffs) after monthly discounts in 2013 to 2015.

Meeting Package; starting at Rp. 110,000 net / person per day (one room two people / twin sharing). The rate (price) for the meeting package, including room accommodation for two people, taxes and services, two coffee breaks, meeting rooms with room capacities ranging from 20 people to 200 people, and a buffet lunch (Buffet Luncheon) in the restaurant.

Following are the results of research on price changes (tariffs) after monthly discounts in 2016 to 2018

Table 1. Price Changes (Rates) After Discounts Per month Superior Single / Double (in Rp) During 2016-2018

\begin{tabular}{|l|l|l|l|l|}
\hline Month & $\begin{array}{l}\text { Room Rate } \\
\mathbf{2 0 1 6}\end{array}$ & $\begin{array}{l}\text { Room Rate } \\
\mathbf{2 0 1 7}\end{array}$ & $\begin{array}{l}\text { Room Rate } \\
\mathbf{2 0 1 8}\end{array}$ & $\begin{array}{l}\text { Average Room } \\
\text { Rate }\end{array}$ \\
\hline January & 353.000 & 345.000 & 400.000 & 366.000 \\
\hline February & 359.000 & 370.000 & 425.000 & 384.667 \\
\hline March & 355.000 & 365.000 & 425.000 & 381.667 \\
\hline April & 360.000 & 365.000 & 435.000 & 386.667 \\
\hline May & 350.000 & 360.000 & 435.000 & 381.667 \\
\hline June & 375.000 & 360.000 & 435.000 & 390.000 \\
\hline July & 360.000 & 370.000 & 440.000 & 390.000 \\
\hline August & 365.000 & 370.000 & 443.000 & 392.667 \\
\hline
\end{tabular}




\begin{tabular}{|l|l|l|l|l|}
\hline Month & $\begin{array}{l}\text { Room Rate } \\
\mathbf{2 0 1 6}\end{array}$ & $\begin{array}{l}\text { Room Rate } \\
\mathbf{2 0 1 7}\end{array}$ & $\begin{array}{l}\text { Room Rate } \\
\mathbf{2 0 1 8}\end{array}$ & $\begin{array}{l}\text { Average Room } \\
\text { Rate }\end{array}$ \\
\hline September & 370.000 & 370.000 & 450.000 & 395.667 \\
\hline October & 360.000 & 365.000 & 450.000 & 391.667 \\
\hline November & 355.000 & 375.000 & 445.000 & 391.667 \\
\hline December & 350.000 & 360.000 & 455.000 & 388.333 \\
\hline
\end{tabular}

Source: 2019 hotels

From these data it can be seen that the room price rates fluctuate, ie in May there was a change in the room price rates which declined which then increased in September.

\section{b. The occupancy rate}

Various marketing efforts have been carried out by the hotel, this is aimed at how customers remain loyal to the places they have visited, not just recognition of the existence of the hotel, but aims that each year the occupancy rate of the rooms provided can be achieved the maximum value.

The percentage of room occupancy in hotels in a year can fluctuate based on month in accordance with the prevailing season in the country. Room occupancy rates in certain months can increase compared to other months, for example occupancy rates between August and November, with a work meeting where the implementation is carried out at the end of the fiscal year based on the remaining funds. Because most agencies follow the mechanism of the procedure, such a budget causes the demand for customers to use hotel services in carrying out its activities to increase quite dramatically compared to the beginning of the year.

In addition, the availability of the budget affects the demand from government agencies, from other user groups who also frequently use the hotel for various purposes, such as social, religious, and student organizations. Therefore, the availability of funds, other factors such as weather or season is very influential on the activities of certain groups of hotel users. Religious organizations, for example, from various groups of Islamic organizations are more likely to carry out their activities during the month of Ramadan. While community organizations and professions, their activities are more likely to adjust to the anniversary of the formation of the organization. These things are quite influential on the fluctuation of the number of requests based on time each year, and the following can be seen the average occupancy rate in the table, which is as follows:

Table 2. Hotel Average Occupancy Rate Structure 2016 - 2018

\begin{tabular}{|l|l|l|l|l|l|}
\hline Month & $\begin{array}{l}\text { Room Sales } \\
\mathbf{2 0 1 6}\end{array}$ & $\begin{array}{l}\text { Room Sales } \\
\mathbf{2 0 1 7}\end{array}$ & $\begin{array}{l}\text { Room Sales } \\
\mathbf{2 0 1 8}\end{array}$ & $\begin{array}{l}\text { average occupancy } \\
\text { rate is 3 years }\end{array}$ \\
\hline January & 0,51 & 0,61 & 0,75 & $62,33 \%$ \\
\hline February & 0,42 & 0,58 & 0,74 & $58 \%$ \\
\hline March & 0,79 & 0,72 & 0,77 & $52,33 \%$ \\
\hline April & 0,33 & 0,67 & 0,80 & $60 \%$ \\
\hline
\end{tabular}




\begin{tabular}{|l|l|l|l|l|}
\hline Month & $\begin{array}{l}\text { Room Sales } \\
\mathbf{2 0 1 6}\end{array}$ & $\begin{array}{l}\text { Room Sales } \\
\mathbf{2 0 1 7}\end{array}$ & $\begin{array}{l}\text { Room Sales } \\
\mathbf{2 0 1 8}\end{array}$ & $\begin{array}{l}\text { average occupancy } \\
\text { rate is 3 years }\end{array}$ \\
\hline May & 0,58 & 0,72 & 0,65 & $65 \%$ \\
\hline June & 0,66 & 0,73 & 0,77 & $72 \%$ \\
\hline July & 0,72 & 0,87 & 0,84 & $81 \%$ \\
\hline August & 0,66 & 0,81 & 0,85 & $78 \%$ \\
\hline September & 0,61 & 0,77 & 0,79 & $72,33 \%$ \\
\hline October & 0,67 & 0,86 & 0,84 & $79 \%$ \\
\hline November & 0,55 & 0,56 & 0,58 & $56,33 \%$ \\
\hline December & 0,91 & 0,83 & 0,74 & $82,6 \%$ \\
\hline
\end{tabular}

Source: 2019 hotels

From the table, it can be seen that the hotel room occupancy rate shows the highest average room occupancy rate at the end of the year which then has decreased and only at the beginning of the year many visitors return.

\section{c. The amount of income}

Sources of reception at the hotel consist of group packages, bungalow rentals, and others. The total revenue ranges from Rp. 19,950,000 to Rp. 24,441,666

The number of receipts tends to vary and fluctuates with fluctuations in the percentage of room occupancy rates as a variable that directly affects it. The number of receipts in January decreased to its lowest point in February. The number of receipts then increased until last April it declined again until July. In August the number of admissions increased again to a constant tendency until December. The pattern of change in the amount of reception is almost the same as the pattern of fluctuations in the percentage of room occupancy. This is because the amount of revenue is fully a function of the occupancy rate from which the sources of revenue are obtained. Total expenditure is a function of fixed costs incurred by the room occupancy rate. The deviation from the total expenditure on the room occupancy rate is due to the fixed costs incurred by the hotel manager that are not related to the presence or absence of room occupancy rates.

In connection with efforts to increase profits by increasing the amount of revenue, it is not simple to just set policies that are expected to directly achieve goals. This interrelated mechanism between these parameters causes the need to consider the chain effects that occur simultaneously. The absolute amount of revenue is influenced by the occupancy rate because the full amount of revenue expected from occupancy payments in other words with the same tariff is not possible to increase the number of receipts without increasing the occupancy rate of the room.

In general, the largest revenue derived from the hotel industry is the sale of rooms (room sales), because usually the purpose of people who come to visit hotels is people who are looking for / need accommodation lodging rooms. But this is not the case at this hotel, maybe some other similar hotels in Puncak 
Bogor, which can then be presented with the results of research on the comparison of hotel reception.

In general, the largest revenue derived from the hotel industry is the sale of rooms (room sales), because usually the purpose of people who come to visit hotels is people who are looking for / need accommodation lodging rooms. But this is not the case at this hotel, maybe some other similar hotels in Puncak Bogor, which can then be presented with the results of research on the comparison of hotel reception.

Table 3. Hotel Reception Comparison, At Puncak-Bogor

(Hundreds of Million Rupiah)

\begin{tabular}{|l|l|l|l|l|l|l|}
\hline Year & $\begin{array}{l}\text { Room } \\
\text { Sales }\end{array}$ & $\begin{array}{l}\text { F\&B } \\
\text { Sales }\end{array}$ & $\begin{array}{l}\text { Other } \\
\text { Operating Dept. }\end{array}$ & Space Rental & $\begin{array}{l}\text { Other } \\
\text { Income }\end{array}$ & $\begin{array}{l}\text { Total } \\
\text { Revenue }\end{array}$ \\
\hline 2016 & 7,12 & 12,37 & 1,08 & 3,07 & 0,30 & 23,94 \\
\hline 2017 & 8,33 & 16,41 & 1,24 & 2,90 & 0,45 & 29,33 \\
\hline 2018 & 9,12 & 20,84 & 0,81 & 3,14 & 0,94 & 34,85 \\
\hline Total & 24,57 & 49,62 & 3,13 & 9,11 & 1,69 & 88,12 \\
\hline \% Share & $27,9 \%$ & $56,3 \%$ & $3,6 \%$ & $10,3 \%$ & $1,9 \%$ & $100 \%$ \\
\hline
\end{tabular}

Source: 2019 hotels

Based on comparative data on the results of sales at the Puncak Bogor Hotel, as illustrated in the table above, it is clearly seen that the accumulation of the largest sales results from 2016 to 2018 is obtained from the sale of food and beverage products, with the amount of shares (share) an average of $56.3 \%$. While the results of the sale of room products occupy the second place, with a share of $27.9 \%$ or in other words food and beverage products become core products while room facilities and other facilities are supporting products. In the record of the acquisition of monthly sales obtained in 2016, that the accumulation of the proceeds from the sale of food and beverage products also continues to dominate and is the largest contributor to the final results (Total Revenue). The magnitude of its shares reached $51.7 \%$ while the amount of room sales results was $29.7 \%$, then the acquisition of room rental (space rental and office space) reached $12.8 \%$ of total revenue.

If we look in more detail from the monthly month, namely the results of the acquisition of the Total Revenue in April 2016 which was the smallest acquisition in the period with the acquisition of the nominal value of the Total Revenue which only reached 1.3 billion, but the magnitude of the shares generated from the sale of food and beverages still first order, i.e.

Food \& Beverage Sales $\times 100 \%$

Total Revenue

$$
\begin{aligned}
& =\frac{0.73}{1.53} \quad \mathrm{X} 100 \% \\
& =47,7 \%
\end{aligned}
$$


While the acquisition of room sales is:

Room Sales X 100\%

Total Revenue

$=\frac{0.51}{1.53} \quad \mathrm{X} 100 \%$

$=33,3 \%$

Furthermore, the following can be presented with sales acquisition data in the following table:

In 2016, the accumulated revenue from food and beverage sales increased to $51.7 \%$ of total revenue and the results of room sales revenue was $29.7 \%$, while the acquisition of space rental sales was $12.8 \%$ of Total Revenue.

Table 4. Acquisition of Sales in 2016

(Tens of Million Rupiah)

\begin{tabular}{|l|l|l|l|l|l|l|l|}
\hline Month & Year & $\begin{array}{l}\text { Room } \\
\text { Sales }\end{array}$ & F\& B Sales & OOD & SP Rental & OI & TR \\
\hline January & 2016 & 0,51 & 1,04 & 0,08 & 0,23 & 0,01 & 1,87 \\
\hline February & 2016 & 0,60 & 0,90 & 0,08 & 0,26 & 0,01 & 1,85 \\
\hline March & 2016 & 0,65 & 1,05 & 0,09 & 0,31 & 0,01 & 2,11 \\
\hline April & 2016 & 0,51 & 0,73 & 0,07 & 0,21 & 0,01 & 1,53 \\
\hline May & 2016 & 0,58 & 0,85 & 0.09 & 0,25 & 0,02 & 1,79 \\
\hline June & 2016 & 0,66 & 1,03 & 0,11 & 0,23 & 0,02 & 2,05 \\
\hline July & 2016 & 0,72 & 1,06 & 0,11 & 0,28 & 0,01 & 2,18 \\
\hline August & 2016 & 0,65 & 1,12 & 0,12 & 0,19 & 0,03 & 2,11 \\
\hline September & 2016 & 0,61 & 1,29 & 0,10 & 0,33 & 0,02 & 2,35 \\
\hline October & 2016 & 0,67 & 1,46 & 0,13 & 0,33 & 0,11 & 2,7 \\
\hline November & 2016 & 0,55 & 1,03 & 0,06 & 0,17 & 0,04 & 1,85 \\
\hline December & 2016 & 0,41 & 0,81 & 0,04 & 0,28 & 0,01 & 1,55 \\
\hline Sub Total & 2016 & 7,12 & 12,37 & 1,08 & 3,07 & 0,30 & 23,94 \\
\hline
\end{tabular}

Source: 2019 hotels

In 2017, the accumulation of revenue from food and beverage sales increased to $54.1 \%$ of total revenue and the results of room sales also increased to $30.8 \%$ while the acquisition of space rental sales decreased to $9.6 \%$ of Total Revenue.

In 2017, the accumulation of revenue from food and beverage sales increased to $54.1 \%$ of total revenue and the results of room sales also increased to $30.8 \%$ while the acquisition of space rental sales decreased to $9.6 \%$ of Total Revenue.

Table 5. Acquisition of Sales in 2017 (Tens of Million Rupiah)

\begin{tabular}{|l|l|l|l|l|l|l|l|}
\hline Month & Year & $\begin{array}{l}\text { Room } \\
\text { Sales }\end{array}$ & $\begin{array}{l}\text { F\& B } \\
\text { Sales }\end{array}$ & $\begin{array}{l}\text { Other Opr } \\
\text { Dept }\end{array}$ & $\begin{array}{l}\text { Space } \\
\text { Rental }\end{array}$ & $\begin{array}{l}\text { Other } \\
\text { Income }\end{array}$ & $\begin{array}{l}\text { Total } \\
\text { Revenue }\end{array}$ \\
\hline January & 2017 & 0,61 & 1,47 & 0,08 & 0,29 & 0,03 & 2,48 \\
\hline February & 2017 & 0,58 & 1,29 & 0,10 & 0,25 & 0,03 & 2,25 \\
\hline March & 2017 & 0,72 & 1,31 & 0,11 & 0,27 & 0,03 & 2,44 \\
\hline April & 2017 & 0,67 & 1,06 & 0,12 & 0,16 & 0,02 & 2,03 \\
\hline
\end{tabular}




\begin{tabular}{|l|l|l|l|l|l|l|l|}
\hline Month & Year & $\begin{array}{l}\text { Room } \\
\text { Sales }\end{array}$ & $\begin{array}{l}\text { F\& B } \\
\text { Sales }\end{array}$ & $\begin{array}{l}\text { Other Opr } \\
\text { Dept }\end{array}$ & $\begin{array}{l}\text { Space } \\
\text { Rental }\end{array}$ & $\begin{array}{l}\text { Other } \\
\text { Income }\end{array}$ & $\begin{array}{l}\text { Total } \\
\text { Revenue }\end{array}$ \\
\hline May & 2017 & 0,72 & 1,30 & 0,29 & 0,22 & 0,03 & 2,36 \\
\hline June & 2017 & 0,73 & 1,34 & 0,11 & 0,22 & 0,03 & 2,43 \\
\hline July & 2017 & 0,87 & 1,66 & 0,12 & 0,25 & 0,06 & 2,96 \\
\hline August & 2017 & 0,81 & 1,56 & 0,11 & 0,20 & 0,03 & 2,71 \\
\hline September & 2017 & 0,77 & 1,51 & 0,10 & 0,28 & 0,03 & 2,69 \\
\hline October & 2017 & 0,86 & 1,92 & 0,16 & 0,34 & 0,08 & 3,36 \\
\hline November & 2017 & 0,56 & 1,14 & 0,06 & 0,16 & 0,03 & 1,95 \\
\hline Decenber & 2017 & 1,43 & 0,85 & 0,08 & 0,26 & 0,05 & 2,67 \\
\hline Sub Total & 2017 & 9,33 & 16,41 & 1,24 & 2,90 & 0,45 & 30,33 \\
\hline$\%$ to Total Revenue & $30,8 \%$ & $54,1 \%$ & $4,1 \%$ & $9,6 \%$ & $1,5 \%$ & $100 \%$ \\
\hline
\end{tabular}

Source: 2019 hotels

Then in 2018, the share of food and beverage sales again increased to reach $59.8 \%$ of the Total Revenue by taking the portion of room sales shares that decreased to reach $26.2 \%$ and the acquisition of space rental to only reach $9.0 \%$ of the acquisition of Total Revenue in 2018.

Then in 2018, the share of food and beverage sales again increased to reach $59.8 \%$ of the Total Revenue by taking the portion of room sales shares that decreased to reach $26.2 \%$ and the acquisition of space rental to only reach $9.0 \%$ of the acquisition of Total Revenue in 2018.

Table 6. Acquisition of Sales in 2017 (Tens of Million Rupiah)

\begin{tabular}{|l|l|l|l|l|l|l|l|}
\hline Month & Year & $\begin{array}{l}\text { Room } \\
\text { Sales } \\
\text { sales }\end{array}$ & $\begin{array}{l}\text { F \& } \\
\text { B }\end{array}$ & $\begin{array}{l}\text { Other } \\
\text { Opr. } \\
\text { Dept }\end{array}$ & $\begin{array}{l}\text { Space } \\
\text { Rental }\end{array}$ & $\begin{array}{l}\text { Other } \\
\text { Income }\end{array}$ & $\begin{array}{l}\text { Total } \\
\text { Revenue }\end{array}$ \\
\hline January & 2018 & 0,75 & 1,42 & 0,09 & 0,26 & 0,04 & 2,56 \\
\hline February & 2018 & 0,74 & 1,53 & 0,07 & 0,27 & 0,03 & 2,64 \\
\hline March & 2018 & 0,77 & 1,60 & 0,08 & 0,24 & 0,05 & 2,74 \\
\hline April & 2018 & 0,80 & 1,66 & 0,10 & 0,27 & 0,04 & 2,87 \\
\hline May & 2018 & 0,65 & 1,26 & 0,07 & 0,39 & 0,08 & 2,45 \\
\hline June & 2018 & 0,77 & 1,97 & 0,06 & 0,21 & 0,08 & 3,09 \\
\hline July & 2018 & 0,84 & 2,06 & 0,07 & 0,21 & 0,06 & 3,24 \\
\hline August & 2018 & 0,85 & 2,19 & 0,06 & 0,33 & 0,05 & 3,48 \\
\hline September & 2018 & 0,79 & 1,82 & 0,06 & 0,30 & 0,08 & 3,05 \\
\hline October & 2018 & 0,84 & 2,25 & 0,07 & 0,27 & 0,14 & 3,57 \\
\hline November & 2018 & 0,58 & 0,82 & 0,03 & 0,09 & 0,06 & 1,58 \\
\hline December & 2018 & 0,74 & 2,26 & 0,05 & 0,30 & 0,23 & 3,58 \\
\hline Sub Total & 2018 & 9,12 & 20,84 & 0,81 & 3,14 & 0,94 & 34,85 \\
\hline $\begin{array}{l}\text { \% to Total } \\
\text { Revenue }\end{array}$ & & $26,2 \%$ & $59,8 \%$ & $2,3 \%$ & $9,0 \%$ & $2,7 \%$ & $100 \%$ \\
\hline
\end{tabular}

Source: 2019 hotels

From the table above it turns out that the results of the sale of food and beverages are large as a result of the activities of hotel guests (both staying and not staying) to freeze meetings such as: meetings, seminars, workshops, training and education (training), exhibitions or what is currently called MICE (Meetings, Incentives, Conference and Exhibition) activities. 
This MICE activity is a core activity or Core Functions that actually involves other functions, such as eating and drinking during the activity, from coffee breaks to lunch or dinner which are usually organized by the committee.

MICE activities that require meeting rooms of various sizes and layouts that are very flexible (location of equipment that can be changed as needed), also require other supporting facilities, including: bedroom accommodation for some meeting participants, instructors, guest speakers, entertainment and sports facilities and other facilities.

Because of this, other income or acquisitions in other Operating Departments arise due to multiplier effects, such as the acquisition of loundry, massage parlor (this acquisition enters the acquisition of a fitness center $=$ OOD) and also the acquisition of food and drink. outside of MICE's official activities, such as eating and drinking in the lounge $\&$ bar, room service, and karaoke. In addition to MICE activities, the acquisition of food and beverages is also triggered by other banqueting activities, such as meeting activities for wedding receptions on a large scale or medium / small scale activities in the restaurant area (cananga restaurant) or by using the facilities of the swimming pool area.

Based on data from sales in 2016 to 2018 as illustrated in the table, it appears that there are several effects of the "season" which resulted in a decrease in sales results. As it is known that the tourism industry, especially hotels will also be affected by the season, among others: the holiday season or holidays / week) and also with the situation or situation of security, economy, trade and others.

In this case, the influence of seasons that occur in certain months, can be seen in the table as follows:

Table 7. Income Per Month (Hundreds Of Million Rupiah)

In the period of 2016-2018

\begin{tabular}{|l|l|l|l|l|}
\hline Month & $\mathbf{2 0 1 6}$ & $\mathbf{2 0 1 7}$ & $\mathbf{2 0 1 8}$ & Average \\
\hline January & 8.270 .000 & 24.800 .000 & 23.033 .333 & 18.700 .000 \\
\hline February & 10.830 .000 & 22.500 .000 & 22.466 .666 & 18.600 .000 \\
\hline March & 14.300 .000 & 24.400 .000 & 24.300 .000 & 21.000 .000 \\
\hline April & 12.867 .000 & 20.300 .000 & 21.433 .333 & 18.200 .000 \\
\hline May & 11.000 .000 & 23.600 .000 & 22.000 .000 & 18.900 .000 \\
\hline June & 11.970 .000 & 24.300 .000 & 25.233 .333 & 20.500 .000 \\
\hline July & 4.270 .000 & 29.600 .000 & 27.933 .333 & 20.600 .000 \\
\hline August & 8.540 .000 & 27.100 .000 & 27.666 .666 & 21.100 .000 \\
\hline September & 16.630 .000 & 26.900 .000 & 26.966 .666 & 23.500 .000 \\
\hline October & 12.250 .000 & 33.650 .000 & 32.100 .000 & 26.070 .000 \\
\hline November & 19.437 .070 & 19.500 .000 & 17.933 .333 & 18.956 .800 \\
\hline December & 37.130 .000 & 36.700 .000 & 32.666 .666 & 35.500 .000 \\
\hline$\Sigma$ & 239.400 .000 & 293.300 .000 & 293.733 .333 & 261.626 .800 \\
\hline Average & 19.950 .000 & 24.441 .666 & 24.477 .777 & 21.802 .233 \\
\hline Source & & & &
\end{tabular}

Source:2019 hotels 
From the analysis of the results of the sale of food \& beverage products mentioned above, it is known that there are a number of month periods that the sales results experienced a sharp decline compared to the acquisition in other months. The influence of the campaign and election period (political situation) that occurred and the existence of long holiday periods (Eid, Christmas and New Year) greatly influenced the acquisition of hotel food and beverage sales in Bogor Peak.

\section{E. Conclusion}

Based on the results of the discussion in descriptive and quantitative analysis at the Hotel in Puncak Bogor, it can be concluded, as follows:

1. Determination of room price rates as measured by the level of occupancy there is an influence on the income received by hotels in Puncak Bogor by not paying attention to aspects of improving service quality, it will not lead to a reduction in income levels.

2. Determination of hotel prices in Puncak Bogor

Using a standard strategy, for services and pricing this can change according to conditions that occur both internally and externally by considering, improving and maintaining existing quality.

3. There is a very real effect between pricing as measured by the room occupancy rate of the amount of income received by the hotel.

4. The occupancy rate per month for 3 years, the period 2013 to 2015 showed a fluctuation, although not too large changes and experienced improvement in occupancy rates in certain months, especially in August November.

From these conclusions, it can be put forward suggestions that can be used by the hotel management in order to increase visitors, namely facilities and accommodation as well as technology must be added along with other supporting facilities, so that the image that is already attached to the community continues to survive.

\section{REFERENCES}

Assauri, Sofjan. (2012). Manajemen Pemasaran. Jakarta: Rajawali ... Gramedia

Kotler \& Keller. (2012). Marketing Management, 14th, Person Education.

Kotler dan Keller.(2009). Manajemen Pemasaran. Jilid I. Edisi ke 13. Jakarta: Erlangga.

Kotler, P \& Armstrong.(2010). Principles of Marketing, thirteen edition. New Jersey: Prentice- Hall, Inc.

Kotler, Philip dan Armstrong. (2001). Prinsip-prinsip Pemasaran Edisi Kedelapan. Jakarta: Erlangga. 
Miller and Miller. Statistic and Chemometrics for Analytical Chemistry. edisi, keenam Molan, Binyamin.(2006). Manajemen Pemasaran. Jakarta: Indeks Kelompok Media. Mudradjat, Kuncoro. Metode Kuantitatif Teori dan aplikasi untuk Bisnis dan Ekonomi. Yogyakarta. UPP AMP YKPN

Priyatno, Duwi. (2010). Paham Analisa Statistik Data dengan SPSS. Mediakom. Yogyakarta. Pustaka Utama

Rahman, Arif. (2010). Strategi Dahsyat Marketing Mix for Small Business Cara Jitu, 2010

Ronald.E. Walpole. Pengantar Statistika, Edisi 3. Penerbit PT. Gramedia, Pustaka Utama. Jakarta

Saladin, Djaslim. (2003). Manajemen Pemasaran. Bandung: Linda Karya.

Sarwono, Jonathan. Metode Penelitian Kuantitaif dan Kualitatif. Yogyakarta: Graha Ilmu.

Sharma, S., \& Srivastava, S. (2018). Relationship between Service Quality and Customer Satisfaction in Hotel Industry. TRJ Tourism Research Journal, 2(1), 42-49. doi:10.30647/trj.v2i1.20

Sugiyono. (2015). Metode Penelitian Kuantitatif Kualitatif dan R\&D. Penerbit Alfabeta.

Sulastiyono, Agus.(2006). Manajemen Penyelenggaraan Hotel. Bandung: Alfabeta, 2006

Supranto, J. Statistik Teori dan Aplikasi. Jilid 2, edisi ke 7

Sutopo dan Suryanto, Adi (2003). Pelayanan Prima. Jakarta: Lembaga Administrasi Negara Republik Indonesia

Swasta dan Hani Handoko. Manajemen Pemasaran: Analisa dan Perilaku Konsumen.

Swastha Dh dan Irawan, Manajemen Pemasaran Modern, Edisi 2, Cetakan 5,

Swastha, Basu. Manajemen Penjualan, Edisi 3. BPFE. Yogyakarta

Tjiptono, Fandy . (2008). Strategi Bisnis Pemasaran. Andi. Yogyakarta, 2008 